\section{CHINA IN BRIEF}

Beijing. The Chinese Academy of Sciences (CAS) has broken a long custom of making closed appointments of senior bureaucrats by announcing that one of its institutes the Institute of Geophysics - will publicly advertise for a new director

A CAS spokesman, Gua Chuan-Jie, called the move "a new attempt to deepen reforms currently being undertaken within the academy". The academy has made reform of rigid personnel policies a priority, and is likely to open other jobs to external candidates.

Geophysics professors under 55 years of age may apply for the job. The successful applicant will get the same privileges as government officials of equivalent rank. The spokesman says: "We do not want a bookworm. The new director should be capable of dealing with society." Applications close on 8 August.

The administration will test a new and powerful satellite launch rocket, Long March 3a, within the next three months. It plans to use it to launch a domestic telecommunications satellite early next year. A larger thrust version - Long March $3 \mathrm{~b}$-is in the pipeline. It should be ready to launch foreign satellites within two years.

China has already launched five foreign satellites, for Sweden, Pakistan and Australia, and has contracts to launch another three. But although China can offer competitive fees, its existing Long March 2 rocket can carry only a small payload. Long March $3 a$ will be able to carry 2.5 tonnes and version $3 b 4.8$.

But loss of an Aussat-2 satellite last year on its launch by a Long March 2 rocket has cast a shadow over the programme. Scientists and éngineers working on the new launchers have made improving reliability a top priority.

China is to create a national network of nature reserves, as part of an effort to cooperate with United Nations programmes and to protect the Chinese countryside from burgeoning development.

China now has 708 nature reserves covering 6 per cent of the land. But most have inadequate infrastructure, lack information services and are poorly managed. Conservationists are frustrated by the lack of coordination between reserves, which fall under various central and provincial government departments.

The new programme was announced by Zhao Xian-Ying, secretary general of the national committee on the UNESCO-led Man and the Biosphere (MAB) programme. It will try to coordinate management of existing reserves, including nine chosen to take part in the international MAB programme.

China plans to have 1,000 nature reserves by the year 2000 . But critics say that the country still lacks a coherent conservation research programme to accompany the proposed network.

\title{
Election focuses concern on future of science in S. Africa
}

Cape Town. South Africa is studying ways to increase graduate numbers in science, medicine and engineering, and maintain its research base, in the run-up to next year's democratic general election.

Both the ruling National Party and the African National Congress (ANC) agree that the education system must produce more technologically competent students. The problem is that the large expansion of the universities over the past decade has mainly benefited graduate numbers in arts and social sciences: the percentage of science and engineering graduates has fallen from 17 to 13 per cent, and those in medicine from 11 to 7 per cent.

This is mainly because most Africans go to schools that lack mathematics and science teachers, and consequently cannot meet the entrance requirements for scientific university courses. Even those who have studied science frequently lack laboratory experience and have poor English skills.

One possible solution is the so-called bridging programmes. These give disadvantaged students training in communication skills and hands-on laboratory experience. The largest of these is the "College of Science" programme started at the University of the Witwatersrand in 1991.

There students complete a special twoyear curriculum after which they can enter the second year of the degree programme. It has since almost doubled its intake of science students. Recently it also extended the programme to engineering.

"This system could serve as a model for colleges in a new tertiary education system," says Robert Charlton, the vice chancellor. One problem is that these students do not qualify for state subsidies. The programme and smaller ones at the University of Cape Town in medicine and engineering have had to rely on funding from the private sector. But the new government is likely to make such programmes a priority for funding.

The ANC has also speculated about adopting the British model of setting national quotas of subsidized places for each discipline and allocating them among the universities. "I think it is a great idea, but I doubt the new government will have the political will to implement it," says Chariton. Its political constituency would probably object to introducing such a system until imbalances in primary and tertiary sectors have been redressed.

One thing is clear: expansion of postsecondary education is unlikely to be oriented towards the universities. Enrolment in higher education ( 17 per cent of those aged between 20 and 24) is already skewed towards the universities (62 per cent). Future growth will probably be directed towards technikons ( 23 per cent) and education colleges ( 15 per cent).

The other main problem facing South African research is that the general standard of its universities is low. They are also heavily oriented towards producing graduates in the arts and social sciences. Many feel that some universities should be downgraded to colleges offering only undergraduate degrees, to concentrate scarce research resources on a few "research" universities. "However sensible this may be, it will be politically very difficult to accomplish," says Charlton.

Khotso Mokhele, vice-president of the Foundation for Research Development, the state funding agency for science, is not against the idea if some research universities would be historically black institutions. "The University of Fort Hare, for example, is an important symbol for black people all over the continent," he says.

Stuart Saunders, vice chancellor of the University of Cape Town, is optimistic about the future of both the Universities of Witwatersrand and Cape Town. They have a greater combined research output (in terms of publications in the Institute for Scientific Information's Science Citation Index) than the eight next-ranking universities in South Africa.

He has also suggested that a Californian model - where different post-secondary institutions offer maximum accreditation with each other to simplify transfers between them - might be preferable to creating distinct research and teaching universities. Saunders also thinks the government should direct research funding away from research councils, state laboratories and strategic industries to the universities, which can use it more efficiently.

"I think that the new government will realize that the retention of this research base is essential not only for the development of this country, but for the whole of sub-Saharan Africa," he says. Charlton, is more circumspect: "Resources are going to decline, and we need therefore to allocate them more selectively. The difficulty will be to persuade everybody that selective allocation of resources is the only way to go."

Whatever the outcome, the universities will next year face the prospect not only of answering to a democratically elected government but also the possibility of being funded through regional authorities instead of the Department of National Education. This will depend on the outcome of continuing constitutional negotiations about what functions the government should delegate to the regions.

Michael Cherry 